\title{
Lineament Analysis Using ASTER Satellite Images in the Southern Part of the Korean Peninsula
}

\author{
Weon-hack Choi ${ }^{1}$, Sung-il Cho ${ }^{1}$, Daiei Inoue ${ }^{2}$, Makoto Yanagida ${ }^{3}$, Dong-hee Park ${ }^{1}$ and Chun-joong Chang ${ }^{1}$ \\ 1. Central Research Institute, Korea Hydro \& Nuclear Power Co., Ltd., Daejeon 305-343, Korea \\ 2. Department of Oversea, Tokyo Electric Power Services Co., Ltd., Tokyo 135-0062, Japan \\ 3. Tokyo branch, Hanshin Consultant Co., Ltd., Tokyo 101-0037, Japan
}

\begin{abstract}
Lineaments are often related to faults and lithologic boundaries and in some cases to geomorphic relief. They can be helpfully utilized by investigating active tectonics as preliminary data. In order to assess the distribution and activity of the lineaments around the coastal area of the Korean Peninsula, we have interpreted lineaments using ASTER (Advanced Space borne Thermal Emission and Reflection Radiometer) images. The lineaments range from $2 \mathrm{~km}$ to $50 \mathrm{~km}$ long and show a dominant NNW-SSE trend. The lineament density along the eastern coast line of the Korean Peninsula is higher than the densities on the southern and western coast lines. The lineament rank is La to Le. However, La and Lb are not in sufficient abundance to have a high possibility to be active. In the Pocheon region, there are Quaternary volcanic activities, and hence there is a possibility of recent crustal movement in this area. We plan to recheck the presence and activity of ASTER lineaments by aerial photographs and field investigations in the future.
\end{abstract}

Key words: Lineament, active tectonic, ASTER image, fault.

\section{Introduction}

The most observable features on satellite images and aerial photographs are linear shapes known as lineaments. They appear as straight or curved lines of different lengths. They are often related to faults and lithologic boundaries and in some cases to geomorphic relief [1]. There are several definitions of these linear features. O' Leary et al. [2] defined a lineament as a mappable, simple or composite linear feature of a surface, whose parts are aligned in a rectilinear or slightly curvilinear relationship. This is the generally accepted definition. Woodruff et al. [3] defined a lineament as a feature that: 1 ) is perceived in an image of a solid planetary body, 2) is linear and continuous, 3) has definable end points and lateral boundaries, 4) has a relatively high length-to width ratio and hence a discernible azimuth, and 5) is shown or presumed to be correlatively related to stratigraphy or geologic

Corresponding author: Sung-il Cho, Ph.D., research fields: structural geology \& hydrogeology. E-mail: chosi4476@khnp.co.kr. structures.

Aerial photographs afford the advantage of flexibility and can provide pictures from different heights, with a variety of scales and resolutions. Satellite images, in particular, are always taken from the same height, at the same time of day, and with the same viewing angle, and have the advantage of consistency and uniformity. The objectives of this study are to interpret lineaments on the Korean Peninsula and to classify the activity order of the lineaments (Fig. 1).

In this study, the lineaments were interpreted from ASTER (Advanced Space borne Thermal Emission and Reflection Radiometer) satellite images. In the case of ASTER interpretation, the global geomorphology can be distinguished at a glance to interpret the outline of the topographical features arrangement. However, it is not possible to observe the subtle geomorphologic texture that indicates the characteristics of active structures, due to the scale of 1 : 100,000 , in contrast with aerial photographs, the scale 


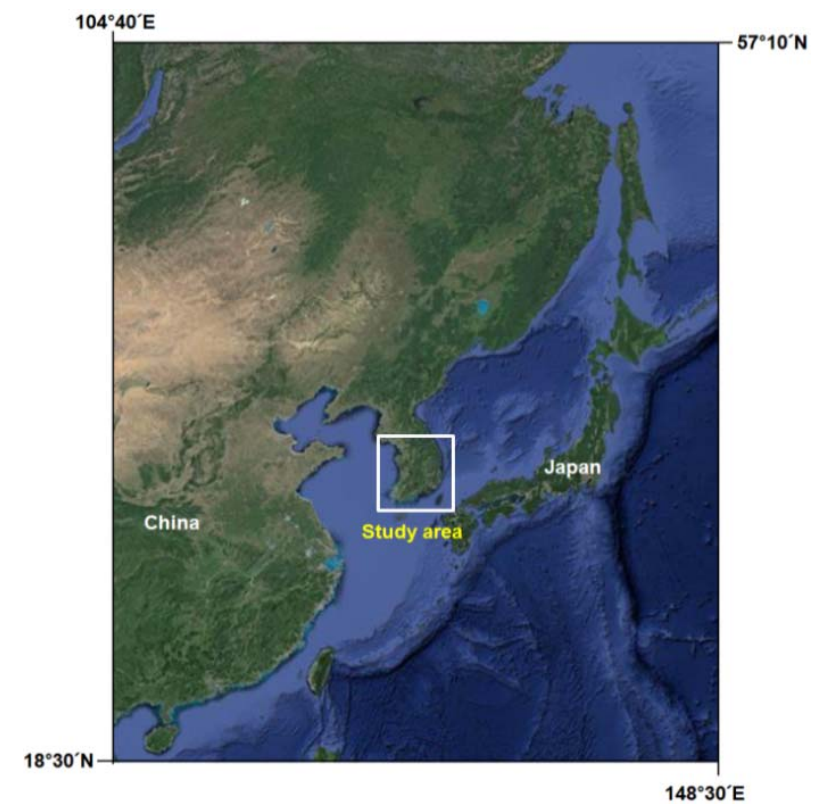

Fig. 1 Location map of the studied area.

of which is $1: 20,000$ or $1: 50,000$, of the studied area; e.g., fault scarps of 10 meter height or offset channels of 10 meters are not recognized by ASTER interpretation. Small scale deformation may be overlooked by this interpretation.

The ASTER is a sensor with 14 band wavelengths that was loaded on the Terra satellite launched by NASA (National Aeronautics and Space Administration) in 1999 [4]. It has characteristic efficiency to view stereoscopic images using the 760-860 nano meter near infrared wavelength band of vertical and backward view ((Visible and Near Infrared band 3N (nadir), 3B (27.6 degrees from nadir)). The height of the satellite is $705 \mathrm{~km}$ above the earth surface; resolution on this stereoscopic band is therefore 15 meters. The ASTER images were enlarged to 1 : 100,000 scale in order to interpret the tectonic geomorphology. The area of one scene image is $60 \mathrm{~km}$ $\times 60 \mathrm{~km}$. To facilitate a simple and easy interpretation, one scene is divided into six sheets. The width of one sheet is A3 size of $420 \mathrm{~mm} \times 297 \mathrm{~mm}$.

\section{Lineament Analysis}

The important technical points of ASTER image interpretation are to observe the large-scale arrangement of topographical features and the height differences of mountains. Lineaments that indicate active tectonics such as active faults, active flexures, etc. are plotted regardless of whether crustal movement is conceivable to explain the above large-scale causes. For example, abrupt changes of mountain height may indicate the presence of a fault that has lifted up the mountain. Nevertheless, it is recommended that existence and activity of lineaments as determined by ASTER images be rechecked by aerial photographs and field investigations. The marine terraces of extensions of lineaments revealed by ASTER should in particular be reexamined by aerial photographs. It is very important for the evaluation to ascertain whether an individual lineament recognized by ASTER affects the deformation on terraces.

When a piedmont line is composed of a straight and steep slope, there may be an active tectonic relief such as potential active faults or buried active faults. On the contrary, it might be alternatively be interpreted as resulting from a differential erosion process by interpreting the surface texture of mountains, valley density, slope inclination, etc. of the surrounding mountains. The ASTER interpretation is superior to the aerial photograph interpretation for this judgment. In this light, ASTER image interpretation can cover a wide range at once and it is possible to compare differences.

Meanwhile, it is relatively easy to observe small fault scarps and offsets of small channels and ridges on terraces by means of aerial photograph interpretation, whereas it is often difficult by means of ASTER interpretation. But ASTER markedly excels in interpreting sharp reverse scarplets when the height differences are more than 20 meters.

The activity order on the lineaments was classified on the basis of Table 1 . The lineaments judged by the ASTER study ranked from $\mathrm{La}$ to $\mathrm{Ld}$. The $\mathrm{La}$ lineaments cannot be recognized in mountainous district geographical features alone. It is conclusive evidence whether there is displacement in a terrace and 
Table 1 Lineament interpretation criteria for the ASTER image.

\begin{tabular}{|c|c|c|c|c|}
\hline \begin{tabular}{|l|} 
Lineament \\
rank
\end{tabular} & Definition & \begin{tabular}{|l|}
$\begin{array}{l}\text { Terraces, small scale } \\
\text { stream }\end{array}$ \\
\end{tabular} & \begin{tabular}{|l|} 
Large scale \\
valley and ridge \\
\end{tabular} & Mountain, hill, basin \\
\hline $\mathrm{La}$ & $\begin{array}{l}\text { Certain } \\
\text { tectonic relief }\end{array}$ & $\begin{array}{l}\text { The cliff and reverse } \\
\text { scarplet in the same } \\
\text { direction are recognized } \\
\text { on the terrace surface and } \\
\text { the talus slope in the } \\
\text { lineament extension. } \\
\text { - There is a reverse } \\
\text { inclination on the higher } \\
\text { terrace and the back of } \\
\text { the hill. } \\
\text { - The lateral offsets are in } \\
\text { plural valley and ridge } \\
\text { systematically develop. }\end{array}$ & $\begin{array}{l}\text { This rank cannot } \\
\text { be recognized in } \\
\text { mountainous } \\
\text { district } \\
\text { geographical } \\
\text { features alone. It } \\
\text { is conclusive } \\
\text { evidence of } \\
\text { whether there is } \\
\text { displacement in } \\
\text { a terrace and a } \\
\text { small-scale } \\
\text { valley. }\end{array}$ & $\begin{array}{l}\text { - This rank cannot be recognized in mountainous district } \\
\text { geographical features alone. It is conclusive evidence of } \\
\text { whether there is displacement in a terrace and a small-scale } \\
\text { valley. }\end{array}$ \\
\hline $\mathrm{Lb}$ & $\begin{array}{l}\text { Probable } \\
\text { tectonic relief } \\
(50 \%)\end{array}$ & $\begin{array}{l}\text { - The cliff and the reverse } \\
\text { scarplet in the same } \\
\text { direction are indistinctly } \\
\text { recognized on the terrace } \\
\text { surface and the talus slope } \\
\text { in the lineament extension. } \\
\text { - The reverse inclination } \\
\text { is presumed to be a higher } \\
\text { terrace and the summit } \\
\text { level of the hill. } \\
\text { - The lateral offsets are in } \\
\text { plural valley and ridge } \\
\text { systematically develop. }\end{array}$ & $\begin{array}{l}\text { Two or more } \\
\text { large valley and } \\
\text { ridge offsets. }\end{array}$ & $\begin{array}{l}\text { - There is discontinuity in the arrangement of large } \\
\text { geographical features and the altitudinal distribution of the } \\
\text { mountainous district, and tectonic movement is assumed to } \\
\text { explain the large geomorphology. } \\
\text { - There are narrow basins and valleys that continue in a } \\
\text { straight direction for considerable length, and tectonic } \\
\text { movement is assumed to explain big geomorphology. } \\
\text { - The foot of a mountain line is consecutively straight line } \\
\text { and steep inclination, and tectonic relief is assumed. }\end{array}$ \\
\hline Lc & $\begin{array}{l}\text { Probable } \\
\text { tectonic relief } \\
(20 \%-30 \%)\end{array}$ & $\begin{array}{l}\text { - Cliff in the same } \\
\text { direction is recognized on } \\
\text { the terrace surface in the } \\
\text { lineament extension, } \\
\text { locally. } \\
\text { - The reverse inclination } \\
\text { is presumed to be a higher } \\
\text { terrace and a summit level } \\
\text { hill. }\end{array}$ & $\begin{array}{l}\text { A part of a large } \\
\text { valley and the } \\
\text { ridge shift } \\
\text { systematically } \\
\text { offsets. }\end{array}$ & $\begin{array}{l}\text { - There is a high discontinuity about the arrangement of } \\
\text { large geographical features and altitudinal distribution of } \\
\text { the mountainous district. However, the terrain feature are } \\
\text { insufficient as a lineament. } \\
\text { - There are narrow basins and valleys that continue in a } \\
\text { straight direction for considerable length. However, the } \\
\text { terrain feature is insufficient as a lineament. } \\
\text { - The foot of the mountain forms a straight line and has a } \\
\text { steep inclination. However, the terrain features are a } \\
\text { insufficient as a lineament. }\end{array}$ \\
\hline $\mathrm{Ld}$ & $\begin{array}{l}\text { Low possibility } \\
\text { of tectonic } \\
\text { relief } \\
\text { (because the } \\
\text { possibility of } \\
\text { the an active } \\
\text { fault cannot be } \\
\text { denied, extract } \\
\text { it for attention) }\end{array}$ & $\begin{array}{l}\text { Scarp on the terrace } \\
\text { surface and lateral offsets } \\
\text { in a small-scale valley } \\
\text { cannot be admitted. }\end{array}$ & $\begin{array}{l}\cdot \text { Offset is not } \\
\text { admitted in a } \\
\text { big valley and } \\
\text { the ridge. } \\
\text { - There are a } \\
\text { valley and a } \\
\text { ridge that are } \\
\text { not offset. }\end{array}$ & $\begin{array}{l}\text { - There is highly discontinuity about arrangement of large } \\
\text { geographical features and altitudinal distribution of the } \\
\text { mountainous district. However, the terrain features are } \\
\text { insufficient as a lineament. } \\
\text { - There are narrow basins and valleys that continue in a } \\
\text { straight direction for considerable length. However, the } \\
\text { terrain features are insufficient as a lineament. } \\
\text { - The foot of the mountain forms a straight line and has a } \\
\text { steep inclination. However, the terrain features are } \\
\text { insufficient as a lineament. }\end{array}$ \\
\hline Le & $\begin{array}{l}\text { No tectonic } \\
\text { relief } \\
\text { (erosional } \\
\text { geomorphology } \\
\text { correlating with } \\
\text { old fault, } \\
\text { bedding } \\
\text { stratification, } \\
\text { and intrusive } \\
\text { boundary) } \\
\end{array}$ & $\begin{array}{l}\text { Scarp on the terrace } \\
\text { surface and lateral offsets } \\
\text { in a small-scale valley } \\
\text { cannot be admitted. }\end{array}$ & $\begin{array}{l}\text { - There is no } \\
\text { systematical } \\
\text { offset of valleys } \\
\text { and ridges. } \\
\text { - It offsets } \\
\text { oppositely. }\end{array}$ & $\begin{array}{l}\text { - There is no discontinuity about the arrangement of large } \\
\text { geographical features and altitudinal distribution of the } \\
\text { mountainous area, although there are straight geographical } \\
\text { features. } \\
\text { - There are narrow basins and valleys that continue in a } \\
\text { straight direction for considerable length. But the } \\
\text { geographical features array bends, and it is regional. } \\
\text { - Although the foot of the mountain line forms straight line and } \\
\text { step slope, the geographical features array bends, and regional. }\end{array}$ \\
\hline
\end{tabular}


a small-scale valley. Those of Lb rank have discontinuity in large geographical features arrangement and the altitudinal distribution of the mountainous district, and requires assumption of tectonic movement to explain large geomorphology. There are narrow basins and valleys that continue in straight, direction for a significant distance, and this requires assumption of tectonic movement to explain the large geomorphology. The Lc lineaments have high discontinuity for the large geographical features and altitudinal distribution of the mountainous district. However, the terrain features are a insufficient as a lineament. Those of Le rank with longer lineaments have been plotted on the sheets. The Le lineaments do not necessarily suggest active faults but may be the result of geological phenomena such as old faults, geological boundaries, etc.

The lineament rank should be regarded as commonly applicable both for ASTER lineament and aerial photograph lineament for the practical use of engineering geology. However, this ASTER interpretation study is a preliminary step; a further analysis of the relationship between ASTER and aerial photograph lineaments in terms of existence is necessary.

\section{Results and Interpretation}

\subsection{Eastern Coast of Korean Peninsula}

The investigated area is along the eastern coast of the Korean Peninsula from the border of North Korea to the city Busan. The analysis range from the coast line is roughly $20 \mathrm{~km}$ into inland, because the goal of this study is to investigate active faults along the coastal line.

Sixty-nine lineaments were interpreted at the eastern Korean Peninsula from 20 sheets of ASTER images (Fig. 2). Long lineaments that do not suggest active fault are also selected to illustrate old faults or geological boundaries. The lineaments dominantly have a NNE-SSW orientation and range from $2 \mathrm{~km}$ to $30 \mathrm{~km}$ long.

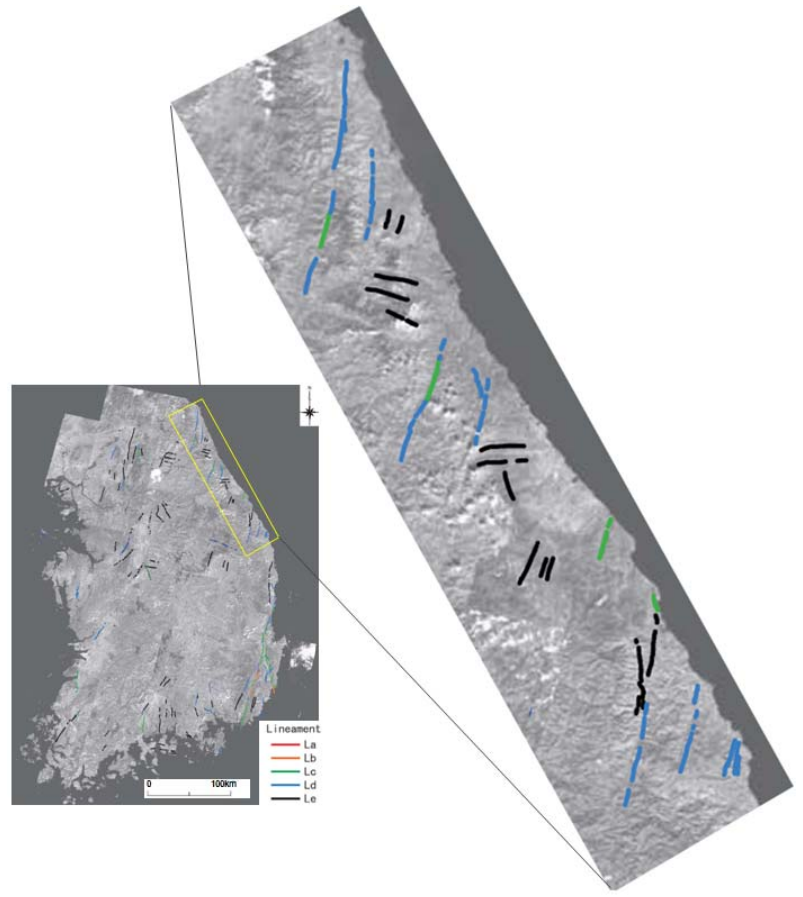

(a) Northern part

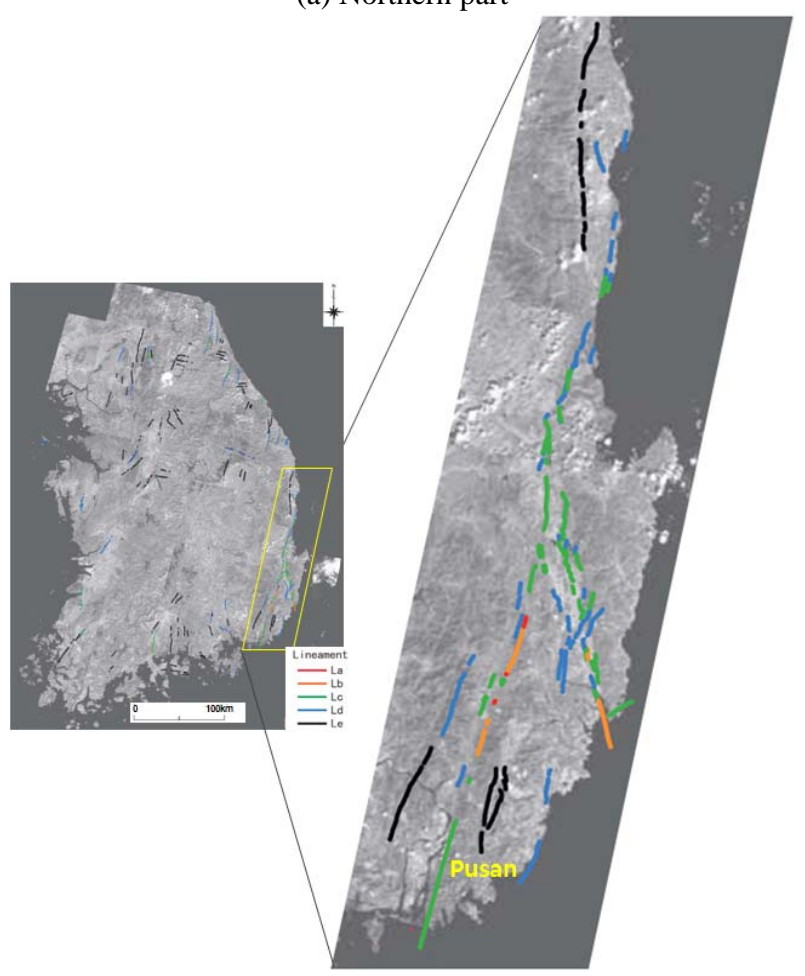

(b) Southern part

Fig. 2 Lineament map interpreted by ASTER image around the eastern coast of the Korean Peninsula.

The lineaments ascertained by the ASTER study are ranked from La to $\mathrm{Ld}$. Those of Le rank with greater length have been plotted on the sheets. The Le lineaments do not necessarily suggest active faults but 
may be the result of geological phenomena such as old faults, geological boundaries, etc.

The Osipcheon fault with a NNE-SSW orientation is situated along the Osipcheon River (Fig. 3). The Osipcheon lineament is divided into three segments. However, the geological faults that may cause the lineament continue without gap as the Osipcheon fault system. The Osipcheon lineament may partly coincide with a geological fault, but the whole line has almost no relationship with the fault shown in the geological map. The Yangsan faults and the Ulsan faults are well known active faults (Fig 3). The Yangsan lineaments are covered by alluvial sediment, and consequently there is no information on activity. There are several dextral offsets of small gorge and ridges. Numerous studies on trench results and active fault outcrops along this lineament have been carried out [5-7].

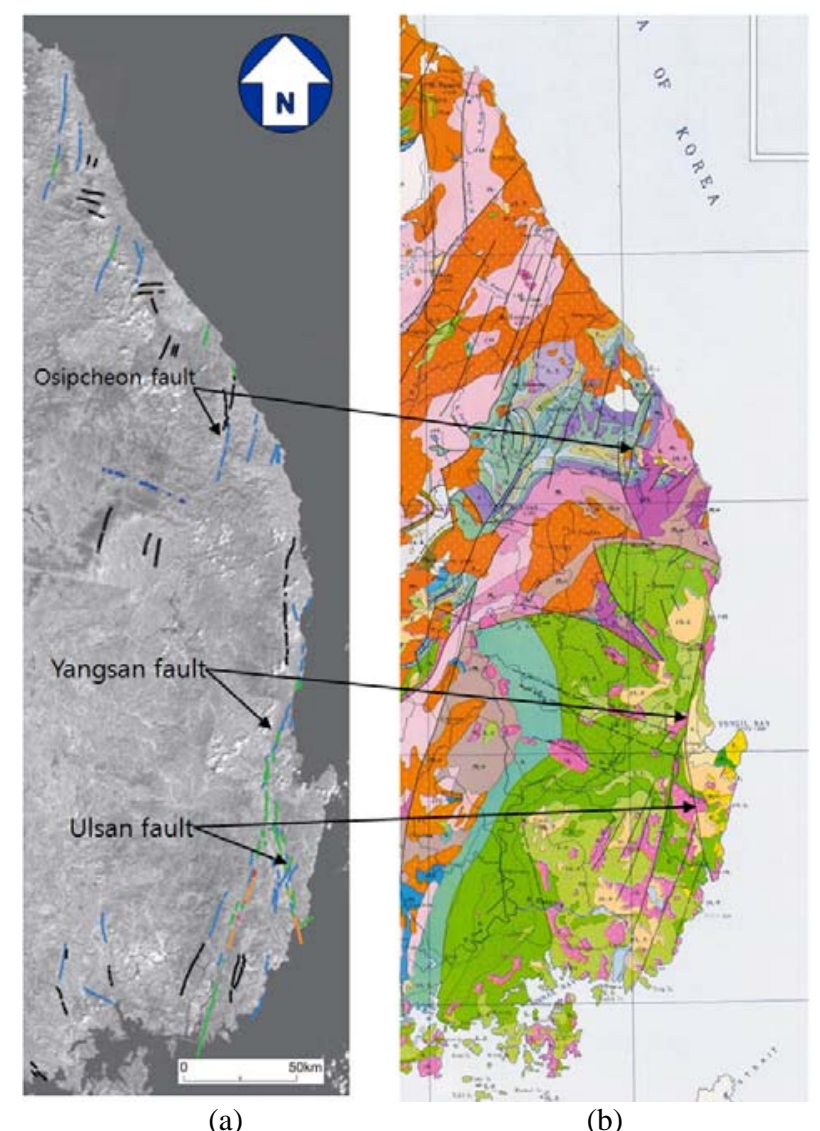

Fig. 3 Comparison of lineaments by ASTER image to geological structures around the eastern Korean Peninsula. (A) Lineaments map by ASTER image, (B) Geological map [8].
The Ulsan lineaments globally have a relationship with the Ulsan fault system that forms the uplift of the eastern mountains. The partial lineaments are interpreted as faults that caused subsidence of the eastern basin. The lineament positions between aerial photographs and ASTER interpretation sometimes differ, because it is difficult to interpret small scale precise geomorphologic features by ASTER. The exact position should be decided by aerial photograph interpretation. ASTER images support that there is an active tectonic topography between mountains and plains.

\subsection{Southern Coast of Korean Peninsula}

The interpretation of ASTER images was carried out from Busan city to Jindo Island via Masan and Gwangyang along the south coast line. The interpretation region to the inland direction is generally about $30 \mathrm{~km}$ from the coast line, but the width differs scene by scene. Twenty-three lineaments were interpreted at the southern part of the Korean Peninsula from 11 ASTER scenes (Fig. 4).

The dominant orientation of the lineaments is NNE-SSW and NE-SW. The lineaments range from 6

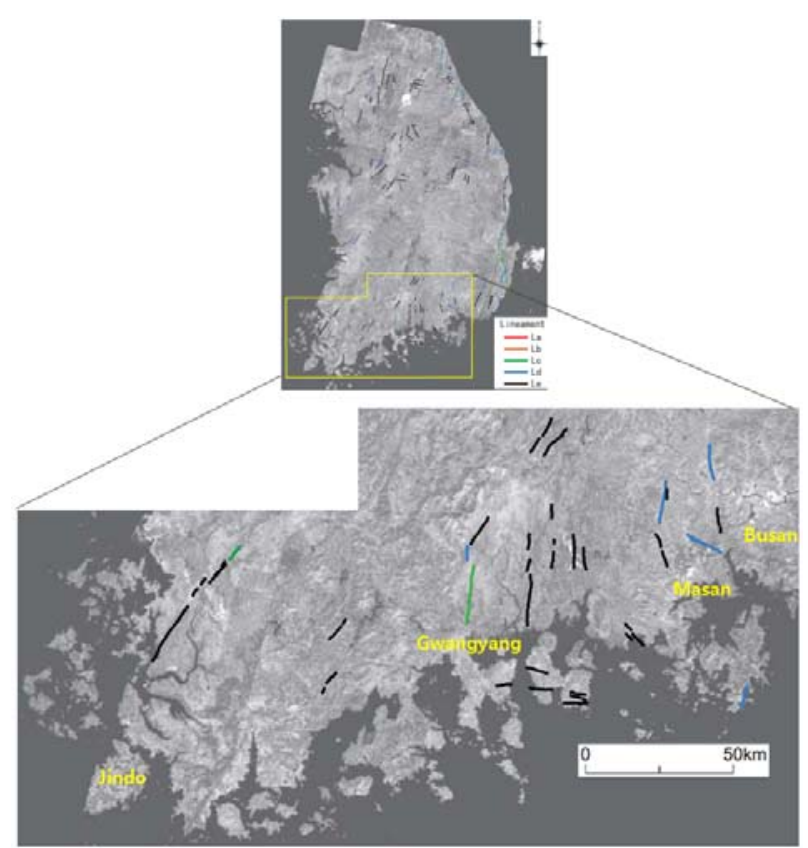

Fig. 4 Lineament map interpreted by an ASTER image around the southern coast of the Korean Peninsula. 
$\mathrm{km}$ to $50 \mathrm{~km}$ long and rank from Lc to Le activity. There are hills of peneplain blocks on the lower land with elevation less than 200 meters in the southern Korean Peninsula. These hills are composed of close valley spacing.

\subsection{Western Coast of Korean Peninsula}

The interpretation region is from Buan to Imjin River along the border with North Korea. Seven lineaments were interpreted. The lineaments have a dominant NNE-SSW orientation and range from $6 \mathrm{~km}$ to $26 \mathrm{~km}$ long (Fig. 5). The lineament rank is Ld and Le, except for the Buan lineament of Lc rank. The Ld and Le rank lineaments have little possibility of being active.

\subsection{Southern Korean Peninsula}

The ASTER interpretation region is about $100 \mathrm{~km}$
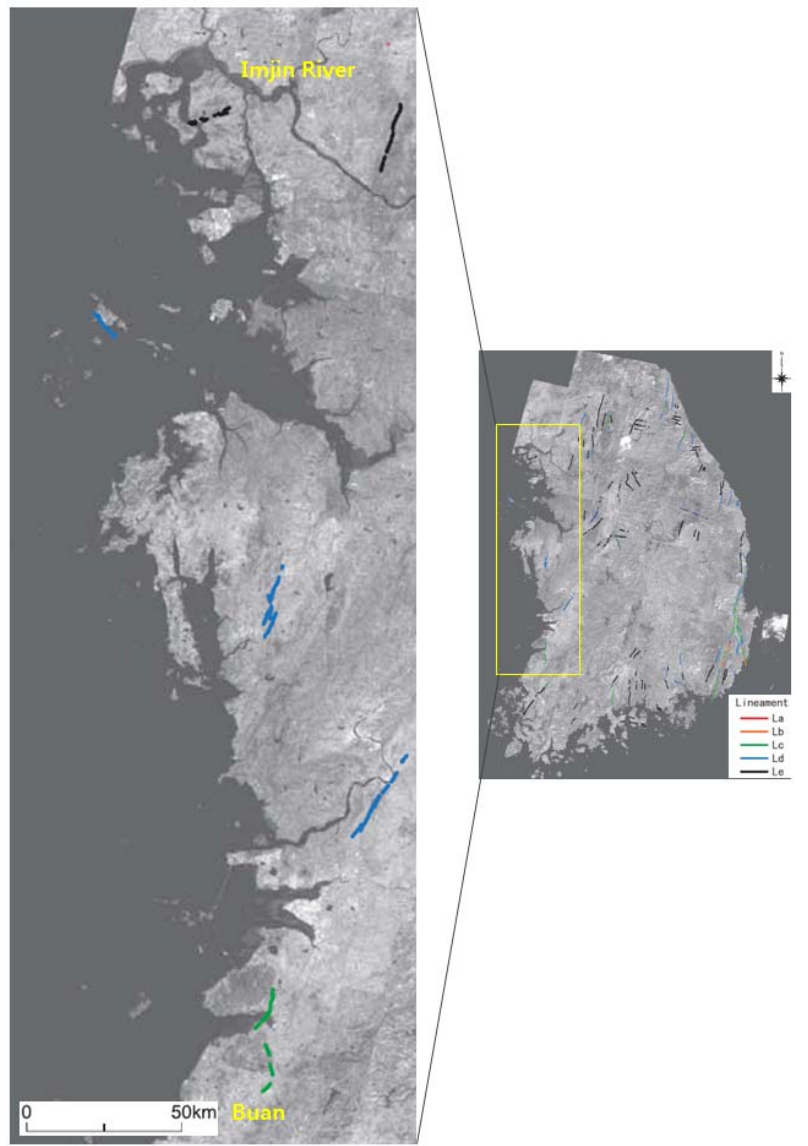

Fig. 5 Lineament map interpreted by ASTER image around the western part of the Korean Peninsula. from north to south and about $60 \mathrm{~km}$ from east to west of Pocheon, Gyeonggi province (Fig. 6).

The lineaments are classified as Lc, Ld and Le. The study area is located north of Seoul. The mountain ranges are distributed in N-S and NNE-SSW directions. According to the geological map with a scale of 1 : 250,000, the Quaternary basalts are colored in this region [9].

Ten lineaments at the Pocheon region are interpreted (Fig. 6). Uplands and hills that were formed by Quaternary volcanic products along the river and in the basin were recognized. These volcanic products are distributed in a $20 \mathrm{~km}$ wide range, and uplands are formed by these rocks. There are volcanic products of several ages, and some of them formed hill topography. Distinct craters or calderas do not remain, but the basin is estimated to be the center of eruption, due to the distribution of huge volcanic products. Looking at the far northern part by means of Google Earth, there are three caldera-like topographies. According to the above geological map, these volcanic products are basalt, but there is another possibility that they are large scale pyro-clastic flow or thin wide flood basalt. In any case, these basaltic rocks were produced during the Quaternary age by monogenetic volcanoes.

There are many lineaments with N-S and NNE-SSW

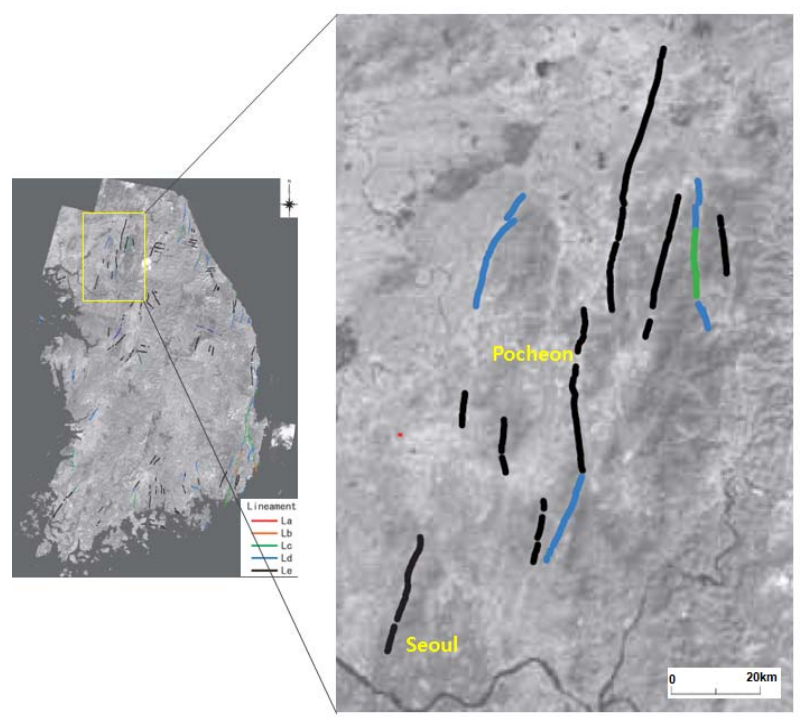

Fig. 6 Lineament map interpreted by ASTER image around the southern part of the Korean Peninsula. 
orientations in the studied area. There are also Quaternary volcanic activities in this area, and hence there may be the possibility of recent crustal movement in this area. The lineament density of this area is higher than that of the coastal area of the Korean Peninsula, and the same density as that of the Yangsan and Ulsan fault areas. However, the lineament rank is lower than that of the Yangsan and Ulsan fault areas.

\subsection{General Interpretation}

\subsubsection{Predominant Orientation of the Lineaments}

Major geological structures of Precambrian gneiss, crystalline schist, granite etc. in Korean Peninsula are oriented in the NNE-SSW direction. The large scale faults that separate large geological structures and divide the Korean Peninsula along the NNE-SSW direction can be easily delineated by using small scale satellite images such as Landsat images. These faults are 200-400 km long. The dominant orientation of lineaments in this study area is also NNE-SSW, consistent with the geological structure (Fig. 3). Kim and Seo [10] released a lineament map of the Korean Peninsula based on a Landsat satellite image (Fig. 7). They reported that the dominant orientation of the lineament is from NNE to NE.

The recent activity may be the inversion movement of old faults. The lineament density along the eastern coast of the Korean Peninsula is higher than that along the southern and western coasts.

\subsubsection{Length of the Lineaments}

Active or probable active parts of faults with a NNE-SSW orientation such as the Osipcheon fault (Fig. 3 ), and several lineaments interpreted by means of ASTER image do not continue for long distances, being from 10 to $40 \mathrm{~km}$ long, compared with the original fault length. The faults that divide the geological distribution continue for several hundred kilometers, based on interpretation of topographic maps. Using ASTER images that correspond to 1 : 100,000 scale topographic maps, it is found that lineaments are interrupted by ridges or hills, and do not continue over long distances.

\subsubsection{Lineaments Activity}

The Yangsan faults and the Ulsan faults are well known active faults (Fig. 4). The Yangsan fault is a right lateral fault and has a NNE-SSW orientation. A lineament that is located near the eastern coast is right lateral with a NNE-SSW orientation. This is ranked as Lc rank. While evidence that the above faults are active has not been confirmed, there is a possibility that they are active, because they have clear topography as active faults. On the other hand, there are only three Ld rank lineaments, and all the others are Le rank lineaments in this study. They are judged to be Le rank because there are no height differences across the lineaments or the lineaments have smooth curves that are free from roughness as a result of being controlled by the schistosity or bedding plane.

\subsubsection{Uneven Distribution of Lineaments}

This is an assumption in terms of the geomorphologic situation that lineaments that are located along the eastern coast line do not continue

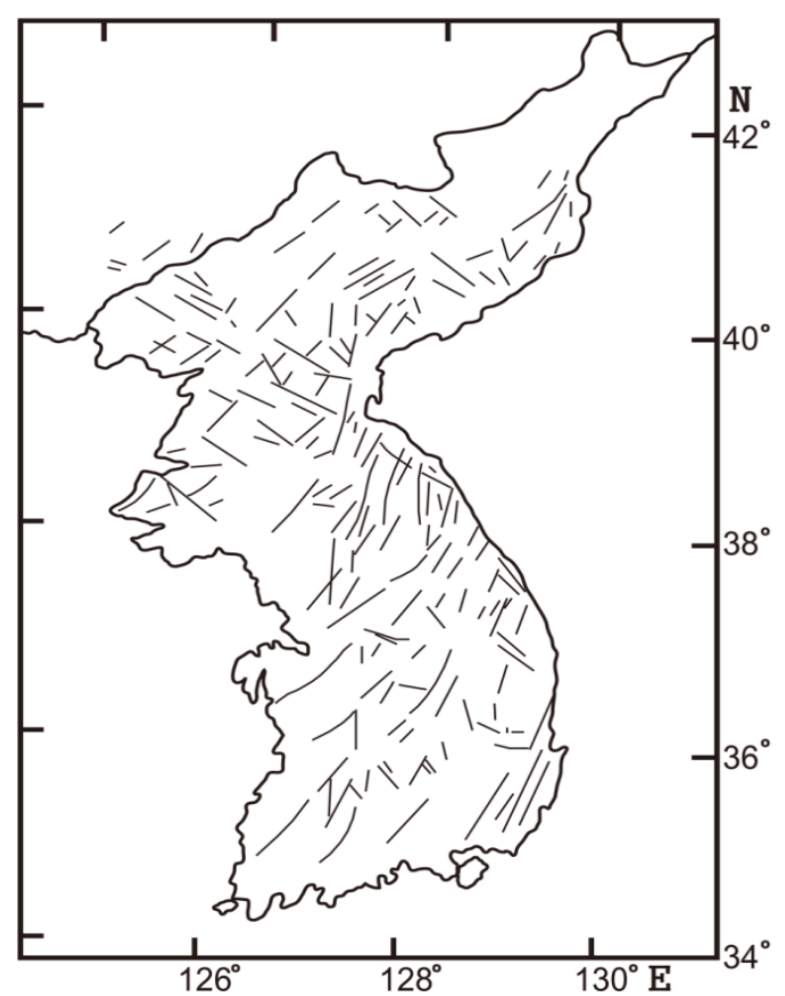

Fig. 7 A lineament map from a Landsat satellite image of Korean Peninsula [10]. 
inland. The faults are more than $100 \mathrm{~km}$ long from a geological point of view, but the lineaments do not continue for long distances and they are distributed fragmentally. Active lineaments, including fragmental lineaments that are unevenly distributed, are limited to the east coast of the Korean Peninsula.

\subsubsection{Long Faults that Form Geological Structure}

Why were the topographic features that correspond to long faults formed? One answer is that intermitted lineaments were formed by the erosion process. On the other hand, the lineaments interpreted by the ASTER image are less than $40 \mathrm{~km}$ long. There are seven NNE-SSW lineaments in this study. One is Lc and Ld, five are Ld, and one is Le. These NNE-SSW orientation lineaments might be active; otherwise, they are remnants that were moved during the Neogene.

\subsubsection{E-W Lineaments}

There are seven E-W orientation lineaments. These lineaments appear to be systematically distributed and have the same separation between them. But the lineaments range from 5 to $34 \mathrm{~km}$ long. It is difficult to estimate the cause of the lineament formation. They may be formed by joints, but if so, the joints were very long. These lineaments might have been formed the differential erosion of different basement rock types.

\section{Future Study}

The lineament rank should be regarded as commonly applicable for ASTER lineaments for the practical use of engineering geology. However, the present ASTER images interpretation study is a preliminary step; analysis of the relationship between ASTER and aerial photograph lineaments with respect to their existence and rank has not yet been carried out. We plan to recheck the existence and activity of ASTER lineaments by aerial photographs and field investigations.

Marine terraces of extended of lineaments revealed by ASTER should in particular be reexamined by aerial photographs. It is very important for the evaluation to determine whether an individual lineament recognized by ASTER affects the deformation on the terrace. Hence, we interpreted the above area by means of ASTER images, considering that we have information on the fault outcrops, the existence of lineaments, and terrace deformation. The ASTER sheet is very convenient to view the broad geomorphologic active tectonics in terms of the cause of geomorphology. We will use both precise lineament maps by large scale aerial photographs and broad active tectonic maps by small scale ASTER images.

\section{Conclusions}

In this study, the lineaments around the coastal area of the Korean Peninsula were interpreted by ASTER images. The lineaments range from $2 \mathrm{~km}$ to $50 \mathrm{~km}$ long and show a dominant NNW-SSE trend, consistent with the geological structure. The lineaments assessed by the ASTER study ranked from La to Le. However, La and Lb are not in sufficient abundance that they would have a high possibility of being active. The lineament density along the Eastern coast of the Korean Peninsula is higher than that along the southern and western coast, respectively. In the Pocheon region, there are Quaternary volcanic activities, and hence there is a possibility of recent crustal movement in this area. We plan to recheck the existence and activity of ASTER lineaments by aerial photographs and field investigations in the future.

\section{Acknowledgments}

This work was supported by a grant under the Radioactive Waste Management Program of the KETEP (Korea Institute of Energy Technology Evaluation and Planning) funded by the Korean Ministry of Trace Industry and Energy (2012171020001).

\section{References}

[1] Hariri, M. 1995. "Lineaments Studies and Fracture Control on the Tertiary Gold-Silver Deposits, Northern Black Hills, South Dakota, USA.” Ph.D. thesis, South Dakota School of Mines and Technology. 
[2] O’ Leary, D., Friedman, D., and Poh, H. 1976. "Lineaments, Linear, Lineations: Some Standards for Old Terms.” Geological Society of America Bulletin 87 (10): 1463-69.

[3] Woodruff, K., Talley, J., and Miller, J. 1982. Selection of Sites for High Productivity Well. Maryland America. Abstracts with Programs. Baltimore: N.E. Geol Soc Am.

[4] Abrams, M., and Ramachadram, S. 2003. ASTER User Handbook. Pasadena: Jet Propulsion laboratory.

[5] Kyung, J. B. 2003. "Paleoseismology of the Yangsan Fault southeastern part of the Korean Peninsula.” Annals of Geophysics 46 (5): 983-96.

[6] Park, Y. D., Ree, J. H., and Yoo, S. H. 2006. "Fault Slip Analysis of Quaternary Faults in Southeastern Korea.” Gondwana Research 9 (1-2): 118-25.
[7] KIGAM (Korea Institute of Geoscience and Mineral Resources). 1995. Geological Map in Korea (1 : 1,000,000). Daejeon: KIGAM.

[8] Inoue, D., and Choi, W. H. 2006. The Activity of the Ulsan Fault System Based on Marine Terrace Age Study at the Southeastern Part of Korean Peninsula. CRIEPI report: N 05012.

[9] KIGAM (Korea Institute of Geoscience and Mineral Resources). 1999. Explanatory Note of the SeoulNamchonjeom Sheet $(1: 250,000)$. Daejeon: KIGAM.

[10] Kim, K. D., and Seo, J. H. 1977. "A Study on the Characteristics and the Causes of Earthquakes in Korea." Jour. Korean Institute of Mineral and Mining Engineers 14 (4): 240-68. 